\title{
Rolf-Heinz Höppner — niemiecki zbrodniarz z Kraju Warty
}

Rolf-Heinz Höppner jest znany przede wszystkim jako autor notatki służbowej z 16 lipca 1941 roku, w której w sześciu punktach zrelacjonował swojemu przełożonemu Adolfowi Eichmannowi ustalenia obrad dotyczących kwestii żydowskiej w Kraju Warty. Bezpośrednio po wojnie notatkę w aktach łódzkiej Centrali Przesiedleńczej odnalazł prokurator Głównej Komisji Badania Zbrodni Niemieckich w Polsce, Julian Leszczyński. Zainteresował się on wkrótce działalnością byłego funkcjonariusza niemieckiego i na podstawie interpretacji dokumentu przypisał mu rolę inicjatora eksterminacji Żydów nie tylko w Kraju Warty, ale także w całej Europie ${ }^{1}$. W 1967 roku w krótkim artykule opublikowanym w „Polityce” stwierdził wprost, że to właśnie Höppner „pierwszy wymyślił masową eksterminację ludzi”" . Błędne założenia Leszczyńskiego spotkały się ze zdecydowaną reakcją ze strony Artura Eisenbacha, wybitnego znawcy tematyki żydowskiej ${ }^{3}$. Paradoksalnie jednak to właśnie formułowane przez Leszczyńskiego poglądy miały pewien wpływ na prowadzone po wojnie postępowania prokuratorskie przeciwko Höppnerowi i wzbudzały zainteresowanie dziennikarzy ${ }^{4}$ oraz historyków osobą autora notatki. Dotychczas jego polityczna aktywność opisy-

1 J. Leszczyński, Z dziejów zagłady Żydów w Kraju Warty (szkice do genezy ludobójstwa hitlerowskiego), „Biuletyn Żydowskiego Instytutu Historycznego” 1972, nr 2, s. 57-71; por. też idem, Od formuty obozu zagłady - Höppner - Chetmno n/Nerem - do „Endlösung”, „Biuletyn Żydowskiego Instytutu Historycznego" 1977, nr 1/101, s. 41-61; idem, Rolf-Heinz Höppner - studium ludobójstwa. Przyczynek do polityki Lebensraumu w II wojnie światowej, „Dzieje Najnowsze” 1972, nr 1, s. 172-174.

2 J. Leszczyński, On byt pierwszy, „Polityka” nr 15, 15 kwietnia 1967 roku.

3 A. Eisenbach, O należyte zrozumienie genezy zagłady Żydów, „Biuletyn Żydowskiego Instytutu Historycznego" 1977, nr 4, s. 55-69.

${ }^{4}$ K. Kąkolewski, Co u pana stychać?, Warszawa 1978, s. 141-172; M. Pollack, Dlaczego rozstrzelali Stanisławów, przeł. A. Kopacki, Wołowiec 2009, s. 20-41. 
wana była przede wszystkim w nawiązaniu do tematyki eksterminacji Żydów ${ }^{5}$. Był to jednak zaledwie jeden z kilku obszarów działalności Niemca.

Höppner należał do kręgu specjalistów i wykonawców nazistowskiej polityki ludnościowej i narodowościowej w Kraju Warty, a jako szef regionalnego biura Służby Bezpieczeństwa był głównym przedstawicielem niemieckiego aparatu terroru w tym okręgu. Przynależał do elit funkcyjnych Kraju Warty, lecz — mimo niemałych ambicji i dużego znaczenia $\mathrm{w}$ regionalnych strukturach wywiadowczych - pozostał funkcjonariuszem średniego szczebla urzędniczego i partyjnego. Jego życiorys i kariera polityczna były charakterystyczne dla przedstawicieli jego pokolenia oraz dla grupy młodych i zaangażowanych intelektualistów nazistowskich, którzy uczestniczyli w zbrodniach III Rzeszy. Po wojnie Höppner odpowiadał przed sądem polskim za swoją działalność. Został uznany za winnego i skazany na dożywocie, ale odbył tylko część kary. Również niemieccy śledczy starali się postawić go przed sądem. Ich nieudane próby są jednym z licznych prowadzonych przeciwko nazistowskim funkcjonariuszom śledztw oraz stanowią przykład trudności w prawnokarnym ,przepracowaniu” przez Republikę Federalną Niemiec brunatnej przeszłości. Höppnerowi, podobnie jak wielu innym niemieckim zbrodniarzom, którzy nie zaliczali się go głównych wykonawców nazistowskiej ideologii, udało się uniknąć odpowiedzialności.

Próba biograficznego ujęcia życia Höppnera — od socjalizacji politycznej poprzez działalność w okresie okupacji niemieckiej w Polsce po losy powojenne - wymaga ukazania uwarunkowań, w których rozwijał on swoją karierę oraz próbował ją później zatuszować. Zadanie to jest o tyle utrudnione, o ile, być może z racji wykonywanych funkcji, pozostawał on w cieniu głównych niemieckich decydentów w Kraju Warty i umiejętnie zacierał po sobie wszelkie ślady. Pomimo tego zachowane materiały źródłowe dostarczają niemało informacji o jego politycznej aktywności. Należy tu wskazać przede wszystkim na szczątkową dokumentację personalną zgromadzoną w Archiwum Federalnym w Berlinie (Bundesarchiv Berlin-Lichterfelde) ${ }^{6}$ oraz na liczne, ale niekompletne (dlatego też często przypadkowe) dokumenty wytworzone przez instytucje mu podległe i zdeponowane w Archiwum II Wojny Światowej Instytutu Zachodniego w Poznaniu? W tym aspekcie bardzo przydatny jest także czwarty tom Documenta Occupationis Teutonicae wydany przez Karola Mariana Pospieszalskiego, biegłego podczas

${ }^{5}$ Należy tu wymienić następuje prace: M. Alberti, Die Verfolgung und Vernichtung der Juden im Reichsgau Warteland 1939-1945, Wiesbaden 2006, s. 358-372; C. Epstein, Wzorcowy nazista. Arthur Greiser i okupacja Kraju Warty, przeł. J. Włodarczyk, Wrocław 2011, s. 181-183; P. Klein, Die „Gettoverwaltung Litzmannstadt” 1940-1944. Eine Dienststelle im Spannungsfeld von Kommunalbürokratie und staatlicher Verfolgungspolitik, Hamburg 2009, s. 336-352.

${ }^{6}$ Archiwum Federalne (Bundesarchiv, dalej: BArch), Berlin Document Center (BDC), SSFührerpersonalakten, Rolf-Heinz Höppner.

7 Archiwum II Wojny Światowej Instytutu Zachodniego w Poznaniu (dalej: I.Z.), Dok. III-3, partyjny urząd ds. narodowościowych; I.Z. Dok. III-9, protokół z przesłuchania Höppnera w więzieniu; I.Z. Dok. I-306, Allgemeine Aktenvermerke oraz pojedyncze dokumenty po partyjnym urzędzie ds. narodowości (od I.Z. Dok. I-232 do I.Z. Dok. I-370). 
rozprawy Höppnera w Poznaniu; przedrukowano w nim kilka dokumentów związanych $\mathrm{z}$ funkcjonariuszem ${ }^{8}$. Najwięcej materiałów poświęconych Höppnerowi przechowywanych jest obecnie w Centrali Badań Zbrodni Narodowosocjalistycznych (Zentrale Stelle der Landesjustizverwaltungen zur Aufklärung nationalsozialistischer Verbrechen) w Ludwigsburgu, która to organizacja koordynowała, inicjowała i współpracowała przy postępowaniach prokuratorskich prowadzonych w latach 60. i 70. XX wieku, m.in. poprzez gromadzenie potencjalnych dowodów 9 . Z kolei w Oddziałowym Archiwum Instytutu Pamięci Narodowej w Poznaniu znajduje się obszerny protokół z rozprawy sądowej z marca 1949 roku $^{10}$. Dokumenty z obu tych instytucji są cenne i nieodzowne nie tylko do opisania postępowania organów śledczych, lecz pomagają też ustalić niektóre szczegóły z życia zawodowego Höppnera. Wymagają one jednak daleko idącej ostrożności, chociażby z tego względu, że podejrzany wiele faktów przemilczał i niejednokrotnie mijał się z prawdą.

\section{Pierwsze doświadczenia polityczne}

Rolf-Heinz Höppner urodził się 24 lutego 1910 roku w niewielkiej saksońskiej miejscowości Siegmar (obecnie dzielnica Chemnitz). W 1916 roku rozpoczął naukę w szkole podstawowej w Chemnitz. Od 1920 roku kontynuował ją w tamtejszym gimnazjum, które ukończył dziewięć lat później uzyskaniem świadectwa dojrzałości ${ }^{11}$. Należał do tego pokolenia młodzieży niemieckiej, któremu brakowało wprawdzie bezpośrednich przeżyć frontowych, ale mimo tego wojna i jej skutki były dla niego kształtującym doświadczeniem tożsamościowym, które będzie miało duże znaczenie w wyborze światopoglądu oraz postawy życiowej ${ }^{12}$. Jesienią 1929 roku Höppner rozpoczął studia prawnicze. Studiował na czterech uczelniach niemieckich: w Halle, Bonn, Fryburgu Bryzgowijskim

8 K.M. Pospieszalski, Niemiecka lista narodowa w „Kraju Warty”: wybór dokumentów z objaśnieniami w języku polskim i francuskim, Documenta Occupationis Teutonicae IV, Poznań 1949.

9 Do najważniejszych należą akta śledztw prowadzonych przeciwko niemu i zgromadzonych obecnie pod sygnaturami: BArch, B 162/17698, Ermittlungsverfahren gegen Höppner; BArch, B 162/20047, Ermittlungsverfahren gegen Höppner; BArch, B 162/20048, Ermittlungsverfahren gegen Höppner. Wskazać należy także na akta śledztwa przeciwko Lotharowi Beutelowi, zob. BArch, B 162/6122, śledztwo ws. działalności Einsatzgruppe IV i L. Beutela.

10 Instytut Pamięci Narodowej (dalej: IPN), Po 796/153, Akta w sprawie karnej przeciwko Rolfowi Heinzowi Höppnerowi i Herbertowi Stricknerowi; IPN, Po 796/152, Akta w sprawie przeciwko Rolfowi Heinzowi Höppnerowi oraz IPN, Po 04/2840, akta dot. H. Stricknera, wytworzone przez Wojewódzki Urząd ds. Bezpieczeństwa Publicznego.

11 BArch, B 162/20047, k. 29-30, życiorys Höppnera.

12 U. Herbert, Werner Best. Studium biograficzne. O radykalizmie, światopoglądzie i rozsądku 1903-1989, przeł. M. Kurkowska, Warszawa 2007, s. 48-50. 
oraz w Lipsku ${ }^{13}$. Studia były dla niego okresem ugruntowania przekonań politycznych związanych z radykalną prawicą. Zainteresowanie ideologią narodowosocjalistyczną potwierdził formalnie w 1930 roku, kiedy, w wieku zaledwie dwudziestu lat, zgłosił swój akces do Narodowosocjalistycznej Niemieckiej Partii Robotników (Nationalsozialistische Deutsche Arbeiterpartei, NSDAP), otrzymując legitymację partyjną o numerze $321209^{14}$. Wstąpienie w szeregi partii hitlerowskiej było wynikiem euforii, która ogarnęła sympatyków ruchu po wyborach do Reichstagu z 14 września 1930 roku. Wówczas to narodowi socjaliści uzyskali ponad 18\% głosów, otrzymując 107 miejsc w parlamencie, a partia przeżyła szturm nowych kandydatów, określanych niekiedy jako „wrześniowi członkowie" 15 . Ponad pół roku później, 1 kwietnia 1931 roku, Höppner wstąpił w szeregi Oddziałów Szturmowych (Sturmabteilungen, SA) — paramilitarnej organizacji NSDAP, których członkiem pozostał przez kolejne cztery lata, do kwietnia 1934 roku $^{16}$. W tym samym roku zakończył edukację wyższą, zdając w styczniu 1934 roku pierwszy egzamin państwowy (Staatsprüfung) z zakresu prawa. Następnie odbył trzyletnią praktykę referendarską w trzech saksońskich miastach: Chemnitz, Hohenstein-Ernstthal oraz Lipsku, którą zakończył w 1937 roku zdaniem drugiego egzaminu państwowego, uzyskując tym samym uprawnienia do wykonywania zawodu ${ }^{17}$. Dla jego politycznej kariery niezwykle ważny był rok 1934. Trzy miesiące po zakończeniu studiów został bowiem zwerbowany do Służby Bezpieczeństwa SS (Sicherheitsdienst, SD) oraz wstąpił do Sztafet Ochronnych NSDAP (Schutzstaffeln, SS) ${ }^{18}$.

Służba Bezpieczeństwa SS była wewnętrzną służbą wywiadowczą NSDAP oraz SS. Powołana została do życia w lipcu 1931 roku przez Reinharda Heydricha, zaufanego współpracownika Heinricha Himmlera, w celu dostarczania informacji o sytuacji wewnątrz partii nazistowskiej oraz przeciwnikach politycznych. Heydrich, a po jego śmierci w maju 1942 roku Ernst Kaltenbrunner, jako szefowie instytucji podporządkowani byli bezpośrednio Himmlerowi. SD długo pozostawała organizacją karłowatą z brakiem odpowiedniego zaplecza organizacyjnego oraz nieliczną obsadą personalną. Sytuacja ta zmieniła się radykalnie po dojściu Hitlera do władzy i po rozgromieniu SA podczas ,nocy długich noży”. SD uzyskała uprawnienia służby państwowej i zajmowała się inwigilacją grup uznanych za wrogów nazizmu (Żydzi, komuniści, masoni) oraz gromadzeniem informacji o społeczeństwie III Rzeszy. Zakres działań służby był nad wyraz szeroki i obejmował w praktyce wszystkie aspekty życia społecznego — od polityki poprzez gospodarkę, kulturę po naukę i edukację. Znacząco wzrosła w latach

\footnotetext{
13 IPN, Po 796/153, k. 11-12.

14 BArch, BDC, Rolf-Heinz Höppner, k. 849.

15 U. Herbert, op. cit., s. 125.

16 BArch, BDC, Rolf-Heinz Höppner, k. 862.

17 BArch, B 162/ 20047, k. 29-30; IPN, Po 796/153, k. 11.

18 BArch, BDC, Rolf-Heinz Höppner, k. 849, 855.
} 
1934-1935 liczba członków SD, których rekrutowano przede wszystkim spośród absolwentów studiów wyższych. Höppner był jednym z nich. Znaczenie Służby Bezpieczeństwa w rozbudowującym się aparacie władzy podległym Himmlerowi potwierdziło podniesienie w styczniu 1935 roku instytucji do rangi głównego urzędu SS (SS-Hauptamt). Pod względem terytorialnym i dla lepszej koordynacji działań wywiadowczych obszary działań SD podzielone zostały na rejony ( $A b$ schnitte) i nadrejony (Oberabschnitte) $\mathrm{SD}^{19}$. Höppner przydzielony został do biura SD w Chemnitz, w swoim rodzinnym mieście, a później przeniesiono go do Lipska, gdzie był odpowiedzialny za ,prasę, kwestię organizacyjne i personalne". Niewykluczone, iż współpracował również z centralą kontroli publikacji (Schrifttumstelle), która zajmowała się cenzurowaniem książek wydawanych w Niemczech ${ }^{20}$. Warto nadmienić, iż Saksonia była, po Bawarii, najstarszym i najważniejszym nadrejonem SD w Rzeszy, a jego pracami kierował początkowo Lothar Beutel. W 1937 roku zastąpił go Wilhelm Koppe, późniejszy wyższy dowódca SS i policji w Kraju Warty ${ }^{21}$. Po zakończeniu praktyk i zdaniu drugiego egzaminu państwowego, na początku 1938 roku został „szefem sztabu” (Stabsführer) w rejonowej placówce kierowniczej SD w Dreźnie (SD-Leitabschnitt) ${ }^{22}$. Przebywał tam do końca kwietnia 1940 roku, kiedy został mianowany na kierownika rejonowej placówki SD w okupowanym już wówczas Poznaniu. Nie wiadomo, jak wyglądało sprawowanie przez niego ponaddwuletniej funkcji w Dreźnie. Nie widnieje on nawet w spisach najważniejszych pracowników tej instytucji, co wskazuje raczej na jego niewielkie znacznie ${ }^{23}$. W sprawozdaniach przełożonych zebranych przy okazji nominacji Höppnera w 1944 roku na stanowisko SS-Obersturmbannführera podkreśla się jedynie jego zaangażowanie w pełnione obowiązki oraz ,silne ideowe oparcie w narodowym socjalizmie" 24 .

\section{Szef SD w Kraju Warty}

W Kraju Warty szybko stał się on ważną postacią niemieckiego aparatu władzy. Przez cały czas pobytu w Poznaniu, czyli od 1 maja 1940 do 30 czerwca

19 U. Herbert, op. cit., s. 173-177, M. Wildt, Generation des Unbedingten. Das Führungskorps des Reichssicherheitshauptamtes, Hamburg 2003, s. 239-251.

20 BArch, B 162/20047, k. 29-30; IPN, Po 796/152, k. 13; Ch. Ingrao, Wierzyć i niszczyć. Intelektualiści w machinie wojennej SS, przeł. M. Kamińska-Maurugeon, Wołowiec 2013, s. 159-161.

21 C. Schreiber, Elite im Verborgenen. Ideologie und regionale Herrschaftspraxis des Sicherheitsdienstes der SS und seines Netzwerkes am Beispiel Sachsens, München 2008, s. 35-49.

22 BArch, B 162/20047, k. 30.

23 Por. C. Schreiber, op. cit., s. 57-62.

24 BArch, BDC, Rolf-Heinz Höppner, k. 851-852. 
1944 roku, był szefem rejonowej placówki kierowniczej Służby Bezpieczeństwa (SD-Leitabschnitt Posen). Również w maju 1940 roku został mianowany zastępcą kierownika Centrali Przesiedleńczej w Poznaniu (Umwandererzentralstelle Posen, $U W Z)^{25}$. Równocześnie ustanowiono go przy Inspektorze Policji Bezpieczeństwa i SD (Inspektor Sicherheitspolizei und SD, IdS) referentem w zakresie spraw UWZ ${ }^{26}$. Z inicjatywy IdS 17 kwietnia 1941 roku Höppner wydelegowany został do Centralnego Urzędu Niemieckiej Listy Narodowościowej w Poznaniu (Zentralstelle der Deutschen Volksliste) ${ }^{27}$, a ponad rok później - 8 maja 1942 roku — objął referat narodowościowy (Volkstumsreferat, I/50) w Urzędzie Namiestnika Rzeszy w Kraju Warty, który odpowiadał za wprowadzanie niemieckiej listy narodowościowej (Deutsche Volksliste, DVL) i etniczną segregację Polaków i Niemców w okręgu ${ }^{28}$. Wreszcie 22 stycznia 1943 roku wyznaczony został na kierownika partyjnego urzędu ds. narodowościowych (Gauamt für Volkstumsfragen $)^{29}$. Höppner zatem skupił w swoim ręku wiele funkcji, które były związane z realizacją podstawowych założeń polityki narodowościowej w Kraju Warty deportacji ludności polskiej, segregacji narodowościowej oraz germanizacji. Jak pokazuje przykład Centrali Przesiedleńczej, sprawował jednocześnie stanowisko jej szefa oraz pełnił wobec niej - jako kierownik biura SD i referent z ramienia IdS - funkcje kontrolne i nadzorcze. W przypadku referatu narodowościowego I/50 oraz urzędu ds. narodowościowych, działającego przy NSDAP, doszło do pomieszania kompetencji oraz zatarcia podziału między instytucją państwową a partyjną. Sam Höppner pełnił stanowiska urzędnicze jako członek SS. Było to zjawisko częste w praktyce wykonywania władzy przez Niemców na ziemiach przyłączonych do Rzeszy, w tym w Kraju Warty ${ }^{30}$.

Niemiec piął się także w strukturze SS. Krótko przed przybyciem do Poznania mianowany został 20 kwietnia 1940 roku SS-Hauptsturmführerem. Niecały rok później, w styczniu 1941 roku awansował na SS-Sturmbannführera, natomiast w czerwcu 1944 roku otrzymał stopień SS-Obersturmbannführera. Zatem w wieku zaledwie 34 lat był podpułkownikiem $\mathrm{SS}^{31}$.

Höppner stanowisko szefa poznańskiej SD przejął od Alberta Rappa, który w kwietniu 1940 roku został przeniesiony do Monachium ${ }^{32}$. Rejonowej placówce kierowniczej SD w Poznaniu podlegały biura w stolicach dwóch pozostałych rejencji Kraju Warty — w Lodzi (SD-Abschnitt Litzmannstadt) oraz w Inowro-

25 IPN, Po 796/153, k. 88; IPN, Po 796/153, k. 440.

26 BArch, B 162/20048, k.69.

27 IPN, GK 62/35, k. 10.

28 BArch, B 162/20048, k.69; IPN, Po 796/153, k. 27-28.

29 BArch, BDC, Rolf-Heinz Höppner, k. 889.

30 D. Pohl, Die Reichsgaue Danzig-Westpreußen und Wartheland: Koloniale Verwaltung oder Modell för zukünftige Gauverwaltung, [w:] Die NS-Gaue. Regionale Mittelinstanzen im zentralischen ,Führerstaat”, red. J. John, H. Möller, T. Schaarchmidt, München 2007, s. 401-402.

${ }^{31}$ BArch, BDC, Rolf-Heinz Höppner, k. 866-874.

32 I.Z. Dok. I-429, Befehlsblatt des Chefs der Sicherheitspolizei und des SD, 1940, s. 34. 
cławiu (SD-Abschnitt Hohensalza) ${ }^{33}$. W strukturze SD w rejencji poznańskiej wyodrębnione zostały jeszcze „niższe odcinki regionalne” — ekspozytury w Środzie Wielkopolskiej, Jarocinie, Lesznie, Wolsztynie, Chodzieży i Szamotułach ${ }^{34}$. Höppner odpowiadał zatem za działalność Służby Bezpieczeństwa w całym okręgu. Od początku wojny uprawnienia SD znaczenie się zwiększyły. Stamtąd m.in. rekrutowano członków grup operacyjnych (Einsatzgruppen), funkcjonujących w Polsce na tyłach Wehrmachtu ${ }^{35}$. Dnia 27 września 1939 roku Służba Bezpieczeństwa została wcielona w struktury Głównego Urzędu Bezpieczeństwa Rzeszy (Reichssicherheitshauptamt, RSHA), a jej zadania rozdzielono ostatecznie pomiędzy dwa urzędy - urząd III-SD w kraju (SD-Inland) oraz urząd VI-wywiad zagraniczny SD (SD-Ausland $)^{36}$. Pod względem personalnym biuro SD w Poznaniu podlegało Inspektorowi Policji Bezpieczeństwa i SD, natomiast pod względem merytorycznym bezpośrednio urzędowi III RSHA ${ }^{37}$. Kierownik placówki wysyłał swoim przełożonym co miesiąc raporty o sytuacji w Kraju Warty i panujących w nim nastrojach społecznych. Służba pracowała poprzez sieć agentów, którzy gromadzili informacje. Spływające z terenu meldunki były opracowywane przez poszczególnych referentów, a z ich cząstkowych sprawozdań powstawał wspólny raport, za którego formę i treść odpowiedzialny był Höppner. Raport trafiał na biurko IdS, a stamtąd po dalszym opracowaniu do RSHA w Berlinie. Podobnie jak w Rzeszy agenci inwigilowali wszystkie obszary życia mieszkańców okręgu, a swoją działalność prowadzili zarówno wśród różnych grup Niemców (pod obserwacją znajdowali się szczególnie niemieccy przesiedleńcy ze Wschodu), jak i wśród Polaków. W tym ostatnim wypadku rozpracowywano m.in. polskie organizacje konspiracyjne, które — z perspektywy władz niemieckich — zagrażały wewnętrznemu bezpieczeństwu Rzeszy ${ }^{38}$. Do większych sukcesów SD mogła zaliczyć zdekonspirowanie 26 lipca 1941 roku Antoniego Bnińskiego, delegata rządu RP na ziemie wcielone do Rzeszy. Aresztowania dokonał Herbert Strickner, jeden z najważniejszych współpracowników Höppnera ${ }^{39}$. Höppner obserwował też innych funkcjonariuszy niemieckich, w tym Arthura Greisera, namiestnika Rzeszy i gauleitera w Kraju Warty, o których zachowaniu i wypowiedziach otrzymywał na bieżąco notatki oraz sporządzał meldunki ${ }^{40}$. Zadania wywiadowcze SD były komplementarne, a niekiedy identyczne z działaniami innych rodzajów

33 M. Alberti, op. cit., s 74.

34 IPN, Po 796/153, k. 15.

35 J. Böhler, K.-M. Mallmann, J. Matthäus, Einsatzgruppen w Polsce, przeł. E. Ziegler-Brodnicka, Warszawa 2009, s. 14-17.

36 P. Longerich, Himmler. Buchalter śmierci, przeł. S. Szymański, J. Skowroński, Warszawa 2014, s. 580-582.

37 IPN, Po 796/153, k. 14.

38 IPN, Po 04/2840, k. 19-30; IPN, Po 796/153, k. 15, 37.

39 E. Makowski, Adolf Bniński (1884-1942), [w:] Wojewoda Adolf hr. Bniński (1884-1942). Sesja okolicznościowa Gułtowy, 13 października 1995 roku, Poznań 1997, s. 43-47.

40 I.Z. Dok. I-306; C. Epstein, op. cit. s. 210, 282. 
niemieckiej policji na ziemiach okupowanych, niewątpliwie jednak w całej tej strukturze SD miała silną pozycję, która zapewniała Höppnerowi nieograniczony wgląd w sytuację wewnętrzną Kraju Warty.

\section{Ekspert ds. deportacji i eksterminacji}

Rapp, poprzednik Höppnera, odpowiedzialny był przede wszystkim za organizację masowych wysiedleń obywateli polskich z Kraju Warty do Generalnego Gubernatorstwa, które były podstawowym instrumentem polityki germanizacji ziem zaanektowanych do III Rzeszy ${ }^{41}$. W tym celu ustanowiony został specjalny sztab, który ostatecznie w końcu kwietnia 1940 roku przemianowany został na Centralę Przesiedleńczą i podporządkowany Służbie Bezpieczeństwa. 21 maja 1940 roku Inspektor Policji Bezpieczeństwa i SD w Kraju Warty, Ernst Damzog wyznaczył na szefa Centrali Przesiedleńczej Höppnera pełniącego od trzech tygodni obowiązki szefa poznańskiej $\mathrm{SD}^{42}$. Formalnie Höppner był zastępcą Damzoga, ale faktycznie to on kierował pracami UWZ. Do jego zadań należała organizacja wysiedleń oraz koordynacja działalności instytucji współdziałających przy deportacjach. UWZ działała przez wiele ekspozytur terenowych, spośród których największe znaczenie zdobył oddział w Łodzi, który z czasem przejął główną rolę w polityce wysiedleń w Kraju Warty oraz, częściowo, poza jego granicami (Zamojszczyzna). Na czele łódzkiego oddziału Centrali Przesiedleńczej stanął Hermann Krumey. Współpraca między Höppnerem a Krumeyem układała się dobrze, a w jej efekcie tylko do połowy marca 1941 roku, kiedy to zawieszono wysiedlenia, z Kraju Warty zostało deportowanych ponad 280 tys. obywateli polskich $^{43}$. W czerwcu 1941 roku Höppner jako ekspert do spraw wysiedleń ludności wydelegowany został do zajętej przez Wehrmacht Jugosławii, gdzie pełnił przejściowo funkcję zastępcy działającej tu grupy operacyjnej Policji Bezpieczeństwa i SD, Wilhelma Fuchsa. Odpowiedzialny był przede wszystkim za deportacje Słoweńców, w tym słoweńskich Żydów ${ }^{44}$.

Wysiedlenia objęły również obywateli polskich pochodzenia żydowskiego. W końcu czerwca 1940 roku kierownik UWZ w Poznaniu przedstawił Adolfowi Eichmannowi projekt przerzutu kilkudziesięciu tysięcy Żydów z getta łódzkiego

41 IPN, Po 796/153, k. 45-52.

42 IPN, Po 796/153, k. 88, 440.

43 BArch, B 162/537, akta dot. wysiedleń Polaków, k. 14; IPN, GK 68, Der Chef der Sicherheitspolizei und des SD Umwandererzentralstele Posen, sygn. 6, plan podziału czynności UWZ; M. Rutowska, Wysiedlenia ludności polskiej z Kraju Warty do Generalnego Gubernatorstwa 19391941, Poznań 2003, s. 29-37.

${ }_{44}$ BArch, B 162/20048, k. 5; J. Leszczyński, Rolf-Heinz Höppner ..., s. 176-177; M. Pollack, op. cit., s. 31-32. 
do Generalnego Gubernatorstwa przy użyciu ciągłej kolumny pojazdów ${ }^{45}$. Miesiąc później, w kolejnym piśmie do Eichmanna, zrezygnował z tego pomysłu, twierdząc, że jego realizacja będzie zbyt kosztowna, i wspominał o innej możliwości „usunięcia Żydów, a mianowicie ich likwidacji" "46. Ten radykalny postulat nie spotkał się jednak z odzewem ze strony najważniejszych władz niemieckich. Wiosną 1941 roku opowiedział się z kolei za pomysłem deportacji ze wschodnich powiatów Kraju Warty do Generalnego Gubernatorstwa ,nieproduktywnych Żydów" ${ }^{47}$. Do problematyki żydowskiej powrócono ponownie w lipcu 1941 roku. W siedzibie namiestnika Rzeszy w Poznaniu zorganizowane zostały wówczas z udziałem kilku funkcjonariuszy — w tym Höppnera — narady, których przedmiotem były sprawy ludności żydowskiej. Konkretnym dowodem jego udziału w tych spotkaniach jest, wspomniana na początku tekstu, notatka służbowa datowana na 16 lipca 1941 roku. Autor streścił w niej główne punkty dotyczące rozwiązania ,problemu” żydowskiego w okręgu, które zostały omówione między uczestnikami rozmów. Jednym z nich miało być stworzenie zbiorczego obozu dla 300 tys. Żydów w pobliżu złóż węgla, do którego sprowadzono by wszystkich Żydów z okręgu. Kolejnym postulatem była propozycja wymordowania ludności żydowskiej, ponieważ, jak to sformułowano, ,,istnieje tej zimy niebezpieczeństwo, że nie da się wyżywić wszystkich Żydów. Należy się zastanowić, czy bardziej humanitarnym rozwiązaniem nie byłoby zlikwidowanie wszystkich Żydów za pomocą jakiegoś szybko działającego środka”. W kolejnym punkcie autor wspomniał o konieczności sterylizacji wszystkich Żydówek w wieku rozrodczym. Notatka ta została przekazana Eichmannowi ${ }^{48}$. Jak wskazuje ostatni, szósty punkt notatki, celem Höppnera było również uzyskanie większego nadzoru nad gettami w Kraju Warty przez odsunięcie prezesa rejencji łódzkiej, Friedricha Übelhöra, zamieszanego w aferę finansową związaną z wyłudzaniem pieniędzy z getta łódzkiego. Nadawca wskazał również, iż do przedstawionych w notatce kwestii nie ustosunkował się Greiser. Najprawdopodobniej Höppner próbował zdyskredytować obu funkcjonariuszy, co umożliwiłoby mu uzyskanie większego wpływu na proces decyzyjny dotyczący eksterminacji Żydów w Kraju Warty. Poniósł jednak porażkę, ponieważ to właśnie Greiser odpowiadał za ,rozwiązania kwestii żydowskiej” w okręgu, a początkowo jego współpracownikiem w tym zakresie został Übelhör ${ }^{49}$. W 1941 roku Höppner został wyłączony z bezpośredniego udziału w planowaniu i przygotowywaniu działań eksterminacyjnych. W tym

45 J. Leszczyński, Rolf-Heinz Höppner..., s. 176.

46 A. Pakentreger, Polityka władz niemieckich tzw. Kraju Warty wobec Żydów, „Biuletyn Żydowskiego Instytutu Historycznego" 1977, nr 4, s. 43.

47 G. Aly, „Endlösung”. Völkerverschiebung und der Mord an den europäischen Juden, Frankfurt am Main 2017, s. 225.

48 J. Leszczyński, Od formuly obozu zagłady..., s. 60-61; M. Grzywacz, Pole eksperymentalne Warthegau. Glossy do pewnych wypowiedzi Edyty Stein, ,Zeszyty Naukowe Centrum Badań im. Edyty Stein” 2014, nr 11, Fenomen Edyty Stein — Das Phänomen Edith Stein, s. 193-194.

49 M. Alberti, op. cit., s. 361-363; C. Epstein, op. cit., s. 182-187. 
miejscu należy też podkreślić, że kierowanie do Eichmanna wymienionych pism było naturalną drogą służbową, a do obowiązków Höppnera należało informowanie przełożonego o wszelkich sprawach dotyczących Żydów w okręgu ${ }^{50}$.

Z kwestią zagłady Żydów Höppner zetknął się ponownie jesienią 1943 roku. Dnia 3 października tego roku uczestniczył bezpośrednio w transporcie słoweńskich Żydów do obozu Auschwitz-Birkenau ${ }^{51}$, a już dzień później znalazł się wśród słuchaczy przemówienia Himmlera w Poznaniu, w którym Reichsführer SS mówił otwarcie o wymordowaniu narodu żydowskiego ${ }^{52}$. W maju 1944 roku prawdopodobnie uczestniczył $\mathrm{z}$ kolei $\mathrm{w}$ rozmowach $\mathrm{w}$ Berlinie, dotyczących ponownego uruchomienia ośrodka masowej zagłady w Chełmnie nad Nerem ${ }^{53}$. Opisane wydarzenia świadczą dobrze o tym, iż Höppner był nie tylko świadom tragicznego losu ludności żydowskiej w okupowanej Europie, lecz opowiadał się również za jej wymordowaniem i uczestniczył pośrednio w tej zbrodni. Poza tym jego notatka służbowa z 1941 roku pozostaje jednym z najważniejszych dokumentów ukazujących etapy kształtowania się procesu „ostatecznego rozwiązania kwestii żydowskiej".

Błyskawiczny rozwój wypadków na froncie wschodnim i seria zwycięstw Wehrmachtu spowodowały, iż kierownik UWZ w Poznaniu ponownie zajął się sprawą wysiedleń Polaków z Kraju Warty. W jego przekonaniu należało przystąpić do deportacji milionów Słowian nienadających się do regermanizacji, a za przedsięwzięcie to odpowiadać miała zreorganizowana Centrala Przesiedleńcza. Dnia 3 września 1941 roku SS-Sturmbannführer Höppner wysłał do Hansa Ehlicha, kierującego wydziałem III B w Głównym Urzędzie Bezpieczeństwa Rzeszy, oraz wspomnianego już Eichmanna z wydziału IV B tejże instytucji, pismo z projektem przebudowy UWZ. Według jego założeń miała ona przeobrazić się w centralną instytucję Rzeszy Niemieckiej, która koordynowałby przesunięcia „obcej narodowościowo" ludności w głąb nowo zdobytych obszarów Związku Radzieckiego. Na kolejnych stronach swojego projektu Höppner szczegółowo opisuje, jak wyobraża sobie pracę nowej Centrali Przesiedleńczej oraz przebieg deportacji ${ }^{54}$. Powołuje się przy tym na doświadczenie wyniesione z organizacji wysiedleń obywateli polskich z Kraju Warty — prawdopodobnie widział siebie jako szefa placówki. I tym razem plany eksperta nie zostały uwzględnione przez nazistowskich planistów. Postulowana przez niego Centrala Przesiedleńcza nigdy nie powstała, a centralnymi planami wysiedleń ludności słowiańskiej zajęli się inni funkcjonariusze III Rzeszy, którzy brali udział w przygotowywaniu ko-

50 IPN, GK 68, sygn. 22, k. 15, przykładowy telegram wysłany do A. Eichmanna; A. Eisenbach, op. cit., s. 56.

51 Sonderausweis Issued to Obersturmbannführer Hoppner (1943). Bulmash Family Holocaust Collection. 2014.1.324b; http://digital.kenyon.edu/bulmash/582 (dostęp: 17.05.2018).

52 J. Leszczyński, Od formuły obozu zagłady..., s. 50.

53 M. Alberti, op. cit., s. 481.

54 I.Z. Dok. I-659, Organisation der Umwandererzentrallstelle; G. Aly, op. cit., s. 278-283. 
lejnych wersji tzw. Generalnego Planu Wschodniego (Generalplan Ost). Wśród nich znalazł się Ehlich, który znał koncepcje Höppnera. Nie wiadomo jednak, na ile miały one wpływ na planistów z RSHA ${ }^{55}$.

Szef SD orientował się też w planach akcji wysiedlenia z Kraju Warty i ,specjalnego potraktowania" (Sonderbehandlung) Polaków chorujących na gruźlicę. Z 30 stycznia 1941 roku pochodzi jego pismo do Oskara Gundermanna, szefa wydziału ds. zdrowia w Urzędzie Namiestnika Rzeszy w Poznaniu, w którym wyraził swoje poparcie dla tego projektu. Najprawdopodobniej rola Höppnera jako eksperta ds. deportacji - miała polegać przede wszystkim na organizacji transportów gruźlików. Zarówno wtedy, jak i rok później, kiedy z identycznym pomysłem wystąpił Greiser, nie doszło do realizacji przedsięwzięcia ${ }^{56}$. Należy przy tym zauważyć, iż Gundermann został w styczniu 1941 roku, a więc gdy pojawiły się pierwsze inicjatywy w tym zakresie, zwerbowany przez Höppnera do współpracy z SD ${ }^{57}$.

We wrześniu 1941 roku Höppner wyjechał z Kraju Warty. Do Poznania powrócił dopiero kilka miesięcy później. Jego absencja była związana z prowadzonym przeciwko niemu wewnątrzpartyjnym śledztwem dotyczącym ,podejrzenia o współudział w fałszowaniu dokumentów”. Grupa funkcjonariuszy SS, wśród których znalazł się Höppner, została oskarżona wówczas o sfałszowanie kilka lat wcześniej wyników sportowych swojego kolegi. Ta z pozoru błaha sprawa przerodziła się w dłuższe postępowanie, a sam Höppner został uznanym winnym zarzucanego mu czynu i otrzymał karę w wymiarze jednego tygodnia aresztu domowego 58 .

Wraz z powrotem do Poznania, najpóźniej na początku maja 1942 roku, rozpoczął się kolejny rozdział w politycznej karierze specjalisty w zakresie polityki ludnościowej w Kraju Warty. Najpierw w maju 1942 roku został mianowany kierownikiem referatu narodowościowego w Urzędzie Namiestnika Rzeszy, a w styczniu 1943 roku objął funkcję szefa partyjnego urzędu ds. narodowościowych. Między obu stanowiskami istniała już wcześniej unia personalna ${ }^{59}$. Nieostry był między nimi też podział zadań ${ }^{60}$. W rękach Höppnera, którego poglądy i działania coraz bardziej się radykalizowały, spoczywało ,sterowanie pracą narodowościową" (Steuerung der Volkstumsarbeit) w okręgu ${ }^{61}$. Kompetencje

55 Generalny Plan Wschodni. Zbiór dokumentów, red. Cz. Madajczyk, Warszawa 1990, s. 1941; Ch. Ingrao, op. cit., s. 231-232.

56 BArch, B 162/17698, k. 93-98; Cz. Łuczak, Pod niemieckim jarzmem..., Poznań 1996, s. 38; idem, Położenie ludności polskiej w Kraju Warty 1939-1945. Dokumenty niemieckie, Poznań 1987, s. 86-94.

57 J. Leszczyński, Z dziejów zagłady Żydów..., s. 65.

58 BArch, BDC, Rolf-Heinz Höppner, k. 869-871.

59 K.M. Pospieszalski, op. cit., s. 237.

60 BArch, B 162/17698, k. 29.

61 K.M. Pospieszalski, op. cit., s. 297, określenie zaczerpnięte z przemowy Höppnera wygłoszonej w styczniu 1943 roku przed współpracownikami. 
Höppnera były bardzo szerokie i niejasne, ale można wyróżnić kilka najważniejszych obszarów jego aktywności. Jako szef partyjnego urzędu ds. narodowości zajmował się on w pierwszej kolejności zagadnieniami germanizacji ludności. Decydował, kto - uwzględniając kryterium rasowe — może być przeznaczony do germanizacji i jak ten proces ma wyglądać. To właśnie instytucje mu podległe, w tym wypadku jako szefowi UWZ w Poznaniu, zorganizowały próbne badania rasowe Polaków w trzech powiatach Kraju Warty, których celem miało być odnalezienie „niemieckiej krwi” i poddanie jej regermanizacji ${ }^{62}$. Selekcję rasową stosowano także wobec dzieci. W podpisanej notatce służbowej z 10 czerwca 1944 roku dotyczącej przymusowej germanizacji polskich dzieci stwierdzał, iż dzieci „niewartościowe rasowo" i nieprzedstawiające „pożądanego przyrostu populacyjnego" powinny zostać „wytępione” (ausmerzen) ${ }^{63}$. Dopuszczał możliwość sterylizacji dzieci ze względów rasowych ${ }^{64}$. Dalej nadzorował wszelkie zadania partyjnego urzędu ds. narodowościowych związane z ,wychowaniem do niemieckości" (Erziehung zum Deutschtum), czyli ze zniemczaniem osób wpisanych do 3. i 4. kategorii niemieckiej listy narodowościowej ${ }^{65}$. Dbał również o integrację i indoktrynację niemieckich przesiedleńców w duchu ideologii narodowego socjalizmu ${ }^{66}$. Najlepiej wyobrażenie Höppnera o narodowościowej i rasowej utopii w Kraju Warty oddaje jego przemówienie wygłoszone z okazji przejęcia partyjnego urzędu ds. polityki narodowościowej. Pośród licznych poruszonych tam zagadnień znalazł się również punkt poświęcony „rozwiązaniu kwestii polskiej" (Lösung der Polenfrage). Za realną możliwość Höppner uważał „wyparcie” (Verdrängung) wszystkich Polaków z Kraju Warty, choć w swoich rozważaniach wspominał również o „fizycznym wyniszczeniu” (physische Vernichtung) tej narodowości. W tym drugim wypadku podkreślał, iż kwestia eksterminacji jest „obca Niemcom” (liegt dem Deutschen nicht), chociaż w tym czasie wymordowano już większą część ludności żydowskiej w Kraju Warty ${ }^{67}$.

W Poznaniu Höppner pozostał do końca czerwca 1944 roku, kiedy został przeniesiony do Berlina. Objął tam jeden z departamentów urzędu III A Głównego Urzędu Bezpieczeństwa Rzeszy, w którym zajmował się sprawami wewnętrznej Służby Bezpieczeństwa ${ }^{68}$. Z administracją III Rzeszy był związany jeszcze

62 K.M. Pospieszalski, op. cit., s. 202-236.

63 BArch, B 162/20048, Aktenvermerk, 10 Juni 1944.

64 BArch, B 162/20048. W tym konkretnym przypadku chodziło o chłopca Oskara Daube, którego matka była Żydówką; M. Pollack, op. cit., s. 33-34.

65 I.Z. Dok. I-257, Richtlinien für die politischen Leiter in der Volkstumspolitik; I.Z. Dok. I-277, Lagermäßige Erfassung der Jugendlichen, deren Eltern in die DVL, Abt.3 und 4 eigenstuft sind.

${ }^{66}$ I.Z. Dok. I-115, ramowy plan ws. zagadnień narodowościowych w Kraju Warty.

67 K.M. Pospieszalski, op. cit., s. 291-292.

68 IPN, Po 796/153, k. 11-12. 
przez ponad rok, ponieważ dopiero 10 lipca 1945 roku został aresztowany we Flensburgu przez Brytyjczyków ${ }^{69}$.

\section{Przed polskim i niemieckim wymiarem sprawiedliwości}

$\mathrm{Na}$ początku sierpnia 1946 roku przetransportowano go do Norymbergi, gdzie zeznawał w sprawie działalności SD na procesie przed Międzynarodowym Trybunałem Wojskowym ${ }^{70}$. 25 lutego 1947 roku został przekazany władzom polskim, a już trzy dni później przewieziono go do Cieszyna, stamtąd natomiast do więzienia w Poznaniu. Nie wiadomo dokładnie, kiedy znalazł się w stolicy Wielkopolski, ale na pewno nie później niż w sierpniu 1947 roku, kiedy został po raz pierwszy przesłuchany ${ }^{71}$. W następnych miesiącach odbywały się kolejne przesłuchania prowadzone przez poznańskiego wiceprokuratora Alfonsa Lehmanna, prawnika z Instytutu Zachodniego w Poznaniu K.M. Pospieszalskiego ${ }^{72}$ oraz pracowników Urzędu Bezpieczeństwa Publicznego. Podczas pobytu w więzieniu i w oczekiwaniu na proces Höppner był pod obserwacją służb komunistycznych, które interesowały się w szczególności organizacją oraz działaniami operacyjnymi niemieckiej Służby Bezpieczeństwa. W raporcie z 24 grudnia 1948 roku pracownik UB, rozpracowujący Niemca, określa go jako „nieprzeciętnie inteligentnego i zrównoważonego człowieka potrafiącego się bardzo dobrze maskować, a nawet w więźniu operować bezczelnością i germańską butą. [...]. Niemniej w czasie badań stwierdziłem u niego symptomy tchórzostwa umiejętnie maskowane arogancją, typ na ogół w śledztwie trudniejszy i przebieglejszy" "73.

Latem 1948 roku prokurator Lehmann przygotował wobec Höppnera i drugiego podejrzanego, wspomnianego już Herberta Stricknera, który przebywał w więzieniu wraz ze swoim dawnym przełożonym, wspólny akt oskarżenia. Podstawą oskarżenia był dekret z 31 sierpnia 1944 roku o wymiarze kary dla faszystowsko-hitlerowskich zbrodniarzy winnych zabójstw i znęcania się nad ludnością cywilną i jeńcami oraz dla zdrajców Narodu Polskiego. Ciężar oskarżenia został położony na działalność wywiadowczą Höppnera i Stricknera w Służbie Bezpieczeństwa $^{74}$.

W dniach od 7 do 12 marca 1949 roku przed Sądem Okręgowym w Poznaniu odbyła się rozprawa przeciwko Höppnerowi i Stricknerowi. Na podstawie zachowanego protokołu można stwierdzić, iż koncentrowała się ona w pierwszej

69 BArch, B 162/20047, k. 30.

70 T. Cyprian, J. Sawicki, Sprawy polskie w procesie norymberskim, Poznań 1956, s. 660-661.

71 IPN, Po 796/153, k. 11-12; k. 47.

72 Pospieszalski sporządził dwa protokoły z przesłuchań Höppnera, zob. I.Z. Dok. III-3 oraz I.Z. Dok. III-9.

73 Po 04/2840, k. 11-14.

74 I.Z. Dok. V-479, Akt oskarżenia z 20 sierpnia 1948 roku. 
kolejności, zgodnie z aktem oskarżenia, na udziale obu Niemców w działalności niemieckiego wywiadu w okresie okupacji. Prokuratorzy starali się zrekonstruować przykładowo okoliczności zatrzymania Adolfa Bnińskiego przez Stricknera. Höppnera pytano również o inne zagadnienia, jak na przykład akcję przeciwko gruźlikom, germanizację dzieci, zadania okręgowego urzędu ds. narodowościowych oraz udział w eksterminacji Żydów. Na pytania prokuratury zasłaniał się niewiedzą lub wypierał się autorstwa przedstawianych mu dokumentów. I tak, przy okazaniu notatki z 16 lipca 1941 roku, powiedział: „Odnośnie do kwestii żydowskiej stwierdzić muszę, iż w chwili mego przybycia do Poznania problem ten na terenie tzw. Kraju Warty był całkowicie rozwiązany. Resztę zagadnień dotyczących Żydów opracowywało bez reszty Gestapo"75.

Dnia 15 marca 1949 roku ogłoszono wyrok. Stickner został uznany winnym zarzucanych mu czynów i skazany na karę śmierci. W stosunku do Höppnera sąd orzekł, iż jest on winny przynależności do Służby Bezpieczeństwa i kierowania jej oddziałem w Poznaniu oraz „działania na szkodę Państwa Polskiego oraz osób spośród ludności cywilnej” poprzez wysiedlenia ludności, grabież jej mienia i germanizowanie. W związku z tym otrzymał on karę dożywotniego więzienia ${ }^{76}$. Niecałe dwa lata później wykonano wyrok śmierci na Stricknerze, tymczasem Höppner został skierowany do więzienia w Sztumie, a następnie do więzienia na Mokotowie w Warszawie, gdzie przebywał prawdopodobnie do końca 1956 roku. W 1951 roku skierował do Bolesława Bieruta list z prośbą o ułaskawienie. W 1956 roku złożył natomiast podanie o przedterminowe zwolnienie ${ }^{77}$, które, dzięki ustawie o amnestii z 27 kwietnia 1956 roku, zostało rozpatrzone pozytywnie i w styczniu 1957 roku Höppner opuścił mury więzienia. Wyjechał do Bad Godesberg pod Bonn i na początku 1958 roku podjął pracę zawodową w banku ${ }^{78}$.

Za symptomatyczny można uznać fakt, że przybycie Höppnera do Niemiec zbiegło się $\mathrm{w}$ czasie $\mathrm{z}$ początkiem prawnego przepracowywania zbrodni nazistowskich w Republice Federalnej Niemiec, czego najbardziej widocznym wyrazem było ustanowienie przez ministrów sprawiedliwości krajów związkowych Centrali Badania Zbrodni Narodowosocjalistycznych. Centrala ustalała nazwiska sprawców zbrodni popełnionych na terenach okupowanych przez Niemcy, zbierała dowody procesowe i prowadziła dochodzenia wstępne, wspomagając właściwe dla miejsca zamieszkania podejrzanych urzędy prokuratorskie $\mathrm{w}$ prowadzeniu śledztw i formułowaniu oskarżen ${ }^{79}$. Pozbawiona była kompetencji wy-

75 IPN, Po 796/153, k. 1-120, cyt.: k. 20. Odnośnie do notatki służbowej Höppnera zob. też IPN, Po 04/2840, k. 57.

76 IPN, Po 796/153, k. 141-146.

77 IPN, Po 796/153, k. 400-401, 438.

78 BArch, B 162/20047, k. 30.

79 P. Marti, Sprawa Reinefartha. Kat powstania warszawskiego czy szacowny obywatel, przeł. B. Ostrowska, Warszawa 2016, s. 187-192; Nationalsozialistische Vernichtungslager im Spiegel deutscher Strafprozesse. Belzec, Sobibor, Treblinka, Chelmno, red. A. Rückerl, München 1977, s. $42-43$. 
konawczych, czyli nie formułowała aktów oskarżenia i nie wszczynała śledztw ${ }^{80}$. Na nazwisko Rolfa-Heinza Höppnera niemieccy śledczy natrafili w 1960 roku w związku z dochodzeniem przeciwko Hermannowi Krumeyowi. Prokuratorzy z Centrali Badania Zbrodni Narodowosocjalistycznych dotarli wówczas do spisu pracowników UWZ. Bardziej szczegółowych informacji o byłym funkcjonariuszu udzielił nijaki Karl Bommrich, który opisał krótko działalność Höppnera w czasie wojny oraz przedstawił jego powojenne losy ${ }^{81}$.

Jednakże przez kolejnych pięć lat nie podejmowano żadnych postępowań przeciwko Niemcowi. Był on przesłuchiwany jako świadek podczas śledztw. Po raz pierwszy Höppner stawił się w prokuraturze na początku 1962 roku, kiedy złożył zeznanie w związku z postępowaniem prowadzonym przeciwko wzmiankowanemu już Wilhelmowi Koppe. Przedstawiono mu wówczas jego notatkę służbową z lipca 1941 roku, której autorstwa zdecydowanie się wyparł ${ }^{82}$. 21 czerwca 1965 roku zeznawał podczas postępowania w sprawie rozstrzelania jeńców radzieckich w obozie koncentracyjnym Gross-Rosen ${ }^{83}$. Tego samego dnia złożył relację dotyczącą dawnego przełożonego z czasów drezdeńskich, Lothara Beutela ${ }^{84}$. Natomiast kilka dni później, 2 lipca 1965 roku, został wezwany do złożenia zeznań na temat obozu Kulmhof w Chełmnie nad Nerem i udziału Heinza Reinefartha w funkcjonowaniu ośrodka zagłady ${ }^{85}$. Rok wcześniej, 30 września 1964 roku, Höppner był świadkiem na procesie Krumeya i Hunsche przed Sądem Krajowym we Frankfurcie nad Menem. Wówczas również zaprzeczył, że miał coś wspólnego z notatką z 1941 roku, twierdząc, że po raz pierwszy widział ją podczas procesu w Poznaniu. Na pytanie, czy wiedział o eksterminacji Żydów w Kraju Warty, odparł, iż miał o tym bardzo ogólne informacje, podobnie jak inni funkcjonariusze niemieccy ${ }^{86}$. Przebieg procesu Krumeya był dobrze znany w Polsce ${ }^{87}$. Po zeznaniu Höppnera Julian Leszczyński opublikował w języku niemieckim w jednym z zeszytów Zachodniej Agencji Prasowej artykuł o okolicznościach sporządzenia omawianej notatki, w którym dobitnie wskazywał na znaczącą rolę, jaką odegrał Höppner w zagładzie ludności żydowskiej w Kraju Warty ${ }^{88}$. Tekst ten zmusił prokuraturę przy Sądzie Krajowym we Frankfurcie nad Menem do podjęcia przeciwko Höppnerowi śledztwa z powodu krzywoprzysięstwa. Nie dopatrzono się jednak znamion czynu karalnego i postępowanie umorzono ${ }^{89}$. Jed-

80 S. Fikus, Trudny spadek dysydentów III Rzeszy w Republice Federalnej Niemiec, Warszawa 2013, s. 161-163.

81 BArch, B 162/1033, Ermittlung gegen Hermann Krumey, k. 8, 62-65.

82 BArch, B 162/20047, k. 31.

83 BArch, B 162/ 5636, Ermittlung gegen Arthur Rödl u. a. (KL Groß-Rosen), k. 618.

84 BArch, B 162/6122, Ermittlung gegen Lothar Beutel, k. 601-602.

85 BArch, B 162/27185, Kulmhof, k. 69-70.

86 BArch, B 162/20047, k. 21.

87 J. Leszczyński, On był pierwszy...

88 BArch, B 162/20047, k. 1-2.

89 BArch, B 162/20047, k. 20-22. 
nocześnie jednak w tym samym czasie prokuratura w Bonn, właściwa ze względu na miejsce zamieszkania Niemca, wszczęła własne postępowanie przeciwko Höppnerowi, w którym postawiono mu, na podstawie kilkukrotnie wspomnianej już notatki służbowej, zarzut „pomocnictwa w morderstwie” (Beihilfe zum Mord), to znaczy udziału w eksterminacji Żydów w Kraju Warty. W styczniu 1966 roku prokurator przesłuchał Höppnera, który jednak konsekwentnie podtrzymywał, że pismo nie zostało sporządzone przez niego, argumentując, iż notatka nie ma podpisu oraz że skrót kancelaryjny „Hö”, umieszczony w lewym górnym rogu pisma, nie pochodzi od jego nazwiska. $\mathrm{W}$ toku dalszego postępowania prokuratorzy skupili się zatem przede wszystkim na wyjaśnieniu owego skrótu ${ }^{90}$. W międzyczasie, 15 kwietnia 1967 roku, w tygodniku „Polityka” ukazał się artykuł J. Leszczyńskiego zatytułowany „On był pierwszy”, w którym autor wskazywał nie tylko na sporządzoną przez Höppnera notatkę służbową oraz przypisał mu decydujący wpływ na politykę eksterminacji III Rzeszy, lecz także oskarżył go o próbę wymordowania Polaków chorujących na gruźlicę i udział w mordowaniu chorych psychicznie w ramach akcji $\mathrm{T} 4{ }^{91}$. Na podstawie tych doniesień prasowych prokurator w Bonn otworzył w 1968 roku kolejne, trzecie już, śledztwo przeciwko Höppnerowi. Również w tym wypadku postawiono mu zarzut pomocnictwa w morderstwie. Trzy lata później śledztwo zostało zamknięte, ponieważ nie udało się udowodnić oskarżonemu zarzucanych mu czynów ${ }^{92}$. O ile Höppner nie miał nic wspólnego z akcją nazistowskiej pseudoeutanazji ${ }^{93}$, o tyle jego udział w planach wysiedlenia i wymordowania gruźlików był raczej bezsporny. Zresztą na prośbę prokuratorów niemieckich Główna Komisja Badania Zbrodni Hitlerowskich w Polsce przesłała dokumenty, z których wynikała rola Höppnera w przygotowywaniu działań przeciwko chorym na gruźlicę. Tym bardziej decyzja organów śledczych wydaje się niezrozumiała ${ }^{94}$.

W 1971 roku prokuratura w Bonn rozpoczęła kolejne dochodzenie, tym razem w sprawie przymusowej germanizacji dzieci, którą nadzorował m.in. były kierownik partyjnego urzędu ds. narodowościowych w Kraju Warty. Śledztwo to trwało kilka lat i zakończyło się sformułowaniem przeciwko Höppnerowi aktu oskarżenia, który 25 lutego 1976 roku został przekazany do bońskiego Sądu Krajowego. W kilkunastostronicowym dokumencie prokuratura sformułowała sześć zarzutów odnoszących się do aktualnego, jak i wcześniejszych śledztw prowadzonych przeciwko Höppnerowi. Główna konstrukcja aktu opierała się na oskarżeniach dotyczących organizacji systemu segregacji ludności oraz działań

${ }^{90}$ BArch, B 162/20047, k. 33-100.

91 J. Leszczyński, On byt pierwszy...

92 BArch, B 162/17698, k. 128-144.

93 Inaczej sądzi G. Aly, twierdząc, iż brał on bezpośredni udział w wymordowaniu osób chorych psychicznie. Twierdzenie to nie jest jednak poparte żadnym dowodem. Zob. G. Aly, op. cit., s. 273-274.

${ }^{94}$ BArch, B 162, 17698, k. 32-37. 
zmierzających do germanizacji dzieci. Prokuratorzy uznali, iż Höppner działał z pobudek rasistowskich i w pełni ,identyfikował się z celami narodowego socjalizmu". Podparciem dla zarzutu nienawiści rasowej była również treść notatki służbowej z 1941 roku. Śledczy oskarżyli go też o próbę dokonania mordu na Polakach chorujących na tuberkulozę ${ }^{95}$. Argumenty prokuratury nie przekonały jednak Sądu Krajowego, który 15 września 1976 roku odrzucił akt oskarżenia, powołując się na wątpliwości związane z udziałem oskarżonego w działaniach germanizacyjnych $^{96}$.

W 1979 roku prokuratura krajowa w Bonn podjęła kolejne, ostatnie już śledztwo przeciwko Höppnerowi. Tym razem oskarżyła go o udział w wymordowaniu tysięcy Żydów w obozie zagłady w Chełmnie nad Nerem. Śledztwo w tej sprawie przejęli następnie prokuratorzy z Kolonii oraz z Dortmundu. Ta ostatnia prokuratura jednak rok później umorzyła postępowanie, nie znajdując — poza notatką z 1941 roku — żadnych nowych dowodów na bezpośredni udział byłego szefa SD w Poznaniu w akcji eksterminacyjnej ${ }^{97}$.

Zamknięcie ostatniego postępowania spowodowało, iż Höppner nie został nigdy w Republice Federalnej Niemiec osądzony za swoją zbrodniczą działalność. Jedyną karą, jaka go spotkała, był kilkuletni pobyt w polskich więzieniach. Jak można wnioskować na podstawie reportażu Martina Pollacka, nie tylko nie poczuwał się do winy, lecz uważał się wręcz za ofiarę ,prześladowań” wymiaru sprawiedliwości ${ }^{98}$. Nie zaistniały okoliczności, aby mógł krytycznie spojrzeć na swoje działania w okresie wojny. Jak się wydaje, stało się wręcz przeciwnie umorzone dochodzenia prokuratorskie mogły go tylko utwierdzać w słuszności wybranej drogi życiowej. Patrząc obiektywnie, należy stwierdzić, iż polityczna kariera Höppnera, sposób jego myślenia oraz motywy działań były typowe dla jego formacji pokoleniowej i nie wyróżniają go z grupy podobnych funkcjonariuszy III Rzeszy. Na ocenę i postrzeganie jego osoby wpłynęła przede wszystkim notatka z 1941 roku, zawężając jednak historyczną interpretację działań Höppnera do jednego aspektu. Tym bardziej pożądane są dalsze badania w tym zakresie, które pozwolą, z jednej strony, lepiej poznać udział Niemca w strukturach policyjnych i partyjnych oraz określić jego rolę w niemieckiej polityce narodowościowej w Kraju Warty, a z drugiej, ocenić i podsumować — zarówno polskie, jak i niemieckie - próby pociągnięcia go do odpowiedzialności.

\footnotetext{
95 BArch, B 162, 20048, k. 65-77.

96 BArch, B 162, 20048, k. 80-107.

97 BArch, B 162, 20047, k. 285-289.

98 M. Pollack, op. cit., s. 30, 36-37.
} 


\section{Bibliografia}

\section{Materiały źródłowe}

Archiwum Federalne (Bundesarchiv, BArch):

Berlin Document Center (BDC), SS-Führerpersonalakten, Rolf-Heinz Höppner;

B 162/1033, Ermittlung gegen Hermann Krumey;

B 162/ 5636, Ermittlung gegen Arthur Rödl u. a. (KL Groß-Rosen);

B 162/6122, śledztwo ws. działalności Einsatzgruppe IV i L. Beutela;

B 162/17698, Ermittlungsverfahren gegen Höppner;

B 162/20047, Ermittlungsverfahren gegen Höppner;

B 162/20048, Ermittlungsverfahren gegen Höppner,;

B 162/27185, Kulmhof.

Archiwum II Wojny Światowej Instytutu Zachodniego w Poznaniu (I.Z.):

Dok. I-115, ramowy plan ws. zagadnień narodowościowych w Kraju Warty;

Dok. I-257, Richtlinien für die politischen Leiter in der Volkstumspolitik I.Z. Dok. I-306, Allgemeine Aktenvermerke;

Dok. I-277, Lagermäßige Erfassung der Jugendlichen, deren Eltern in die DVL, Abt.3 und 4 eigenstuft sind;

Dok. I-429, Befehlsblatt des Chefs der Sicherheitspolizei und des SD, 1940;

Dok. I-659, Organisation der Umwandererzentrallstelle;

Dok. III-3, partyjny urząd ds. narodowościowych;

Dok. III-9, protokół z przesłuchania Höppnera w więzieniu;

Dok. V-479, Akt oskarżenia z 20 sierpnia 1948 roku.

Bulmash Family Holocaust Collection.

Instytut Pamięci Narodowej (IPN):

GK $62 / 35$;

GK 68, Der Chef der Sicherheitspolizei und des SD Umwandererzentralstele Posen;

Po 796/152, Akta w sprawie p-ko Rolf Heinz Höppner;

Po 796/153, Akta w sprawie karnej przeciwko Rolfowi Heinzowi Höppnerowi i Herbertowi Stricknerowi;

IPN, Po 04/2840, akta dot. H. Stricknera, wytworzone przez Wojewódzki Urząd ds. Bezpieczeństwa Publicznego;

„Polityka” nr 15, 15 kwietnia 1967 roku;

Pospieszalski K.M., Niemiecka lista narodowa w „Kraju Warty”: wybór dokumentów z objaśnieniami w języku polskim i francuskim, Documenta Occupationis Teutonicae IV, Poznań 1949.

\section{Opracowania}

Alberti M., Die Verfolgung und Vernichtung der Juden im Reichsgau Warteland 1939-1945, Wiesbaden 2006.

Aly G., ,Endlösung”. Völkerverschiebung und der Mord an den europäischen Juden, Frankfurt am Main 2017.

Böhler J., Mallmann K.-M., Matthäus J., Einsatzgruppen w Polsce, przeł. E. Ziegler-Brodnicka, Warszawa 2009.

Cyprian T., Sawicki J., Sprawy polskie w procesie norymberskim, Poznań 1956.

Eisenbach A., O należyte zrozumienie genezy zagłady Żydów, „Biuletyn Żydowskiego Instytutu Historycznego" 1977, $\mathrm{nr} 4$.

Epstein C., Wzorcowy nazista. Arthur Greiser i okupacja Kraju Warty, przeł. J. Włodarczyk, Wrocław 2011. 
Fikus S., Trudny spadek dysydentów III Rzeszy w Republice Federalnej Niemiec, Warszawa 2013. Generalny Plan Wschodni. Zbiór dokumentów, red. Cz. Madajczyk, Warszawa 1990.

Grzywacz M., Pole eksperymentalne Warthegau. Glossy do pewnych wypowiedzi Edyty Stein, „Zeszyty Naukowe Centrum Badań im. Edyty Stein” 2014, nr 11, Fenomen Edyty Stein - Das Phänomen Edith Stein.

Herbert U., Werner Best. Studium biograficzne. O radykalizmie, światopogladzie i rozsądku 1903-1989, przeł. M. Kurkowska, Warszawa 2007.

Ingrao Ch., Wierzyć i niszczyć. Intelektualiści w machinie wojennej SS, przeł. M. Kamińska-Maurugeon, Wołowiec 2013.

Kąkolewski K., Co u pana stychać?, Warszawa 1978.

Klein P., Die „,Gettoverwaltung Litzmannstadt” 1940-1944. Eine Dienststelle im Spannungsfeld von Kommunalbürokratie und staatlicher Verfolgungspolitik, Hamburg 2009.

Leszczyński J., Od formuły obozu zagłady - Höppner - Chetmno n/Nerem - do „Endlösung”, „Biuletyn Żydowskiego Instytutu Historycznego” 1977, nr 1/101.

Leszczyński J., Rolf-Heinz Höppner - studium ludobójstwa. Przyczynek do polityki Lebensraumu w II wojnie światowej, „Dzieje Najnowsze” 1972, nr 1.

Leszczyński J., Z dziejów zagłady Żydów w Kraju Warty (szkice do genezy ludobójstwa hitlerowskiego), „Biuletyn Żydowskiego Instytutu Historycznego” 1972, nr 2.

Longerich P., Himmler. Buchalter śmierci, przeł. S. Szymański, J. Skowroński, Warszawa 2014.

Łuczak Cz., Położenie ludności polskiej w Kraju Warty 1939-1945. Dokumenty niemieckie, Poznań 1987.

Łuczak Cz., Pod niemieckim jarzmem (Kraj Warty 1939-1945), Poznań 1996.

Makowski E., Adolf Bniński (1884-1942), [w:] Wojewoda Adolf hr. Bniński (1884-1942). Sesja okolicznościowa Gultowy, 13 października 1995 roku, Poznań 1997, s. 27-49.

Marti P., Sprawa Reinefartha. Kat powstania warszawskiego czy szacowny obywatel, przeł. B. Ostrowska, Warszawa 2016.

Nationalsozialistische Vernichtungslager im Spiegel deutscher Strafprozesse. Belzec, Sobibor, Treblinka, Chelmno, red. A. Rückerl, München 1977.

Pakentreger A., Polityka władz niemieckich tzw. Kraju Warty wobec Żydów, „Biuletyn Żydowskiego Instytutu Historycznego" 1977, nr 4.

Pohl D., Die Reichsgaue Danzig-Westpreußen und Wartheland: Koloniale Verwaltung oder Modell für zukünftige Gauverwaltung, [w:] Die NS-Gaue. Regionale Mittelinstanzen im zentralischen „Führerstaat”, red. J. John, H. Möller, T. Schaarchmidt, München 2007, s. 395-405.

Pollack M., Dlaczego rozstrzelali Stanisławów, przeł. A. Kopacki, Wołowiec 2009.

Rutowska M., Wysiedlenia ludności polskiej z Kraju Warty do Generalnego Gubernatorstwa 19391941, Poznań 2003.

Schreiber C., Elite im Verborgenen. Ideologie und regionale Herrschaftspraxis des Sicherheitsdienstes der SS und seines Netzwerkes am Beispiel Sachsens, München 2008.

Wildt M., Generation des Unbedingten. Das Führungskorps des Reichssicherheitshauptamtes, Hamburg 2003.

\section{ROLF-HEINZ HÖPPNER - A GERMAN WAR CRIMINAL FROM THE WARTHELAND}

\section{Summary}

Rolf-Heinz Höppner was a German official and a member of young Nazi intellectuals and experts, who created the population and national policy. During the German occupation in Poland he was a head of Security Service of SS in Poznan. He headed also another institution. The position that he held gave him a real impact on the policies pursued against the population in the oc- 
cupied territories. His activities included: gathering information on the moods of the people of the Wartegau, organizing the expulsions of Poles and Jews to the General Government and conducting germanization policy against the Poles. He is best known, however, as the author of a note to Adolf Eichmann from 1941, in which he described the possible ways of using and exterminating the Jewish population.

This article is an attempt at a biographical description of Höppner's activities. First, the stages of political socialization and the first political experiences of German are described. The second and largest part of the text is the characteristics of his activity in the Wartegau. Than are presented his post-war fates and attempts - taken by the Polish and German jurisdiction — to judge and punish Höppner for the committed crimes.

Keywords: Rolf-Heinz Höppner, Security Service of SS, germanization, extermination of Jews, expulsions, judgement of nazi criminals.

Bogumił Rudawski

rudawski@iz.poznan.pl 